\title{
INCREASE IN ALDOSTERONE SECRETION BY CAROTID ARTERY CONSTRICTION IN THE DOG AND ITS PREVENTION BY THYROCAROTID ARTERIAL JUNCTION DENERVATION *
}

\author{
By FREDERIC C. BARTTER, IVOR H. MILLS $\dagger$ AND DONALD S. GANN \\ (From the Section on Clinical Endocrinology, National Heart Institute, Bethesda, Md.)
}

(Submitted for publication November 2, 1959; accepted February 5, 1960)

\begin{abstract}
Although it has been shown that the vagus nerves may carry impulses mediating decreases in the rate of aldosterone secretion (1), no equivalent pathway has been demonstrated which might mediate increases in aldosterone secretion. Because of evidence that aldosterone secretion may be increased by some function of a decreased intravascular volume (2), and the evidence cited above that this increase is not dependent upon the integrity of intrathoracic vagal receptors (1), the present experiments were designed to investigate the role of receptors located in the arterial system.
\end{abstract}

\section{METHODS}

Acute experiments were performed on mongrel dogs under pentobarbital anesthesia. The lumboadrenal veins were cannulated (3) and blood samples were collected intermittently for determination of aldosterone by Mills, Casper and Bartter's modification (1) of the method of Neher and Wettstein (4). This method has an absolute sensitivity of $0.1 \mu \mathrm{g}$ of aldosterone. Losses during extraction and chromatography were determined on every sample by adding $\mathrm{C}_{14}$-cortisone to each specimen before extraction and counting the cortisone region on the final chromatogram after development of the soda fluorescence. The mean recovery rate was $42 \pm 9$ per cent (SD). The overall sensitivity, considering the amount of the sample taken for analysis and the recovery rate, was 0.5 $\mu \mathrm{g}$ per hour. The final value was corrected for all losses by dividing each observed value by the rate of recovery of that sample. Thus, the only variable altering reproducibility is that of measurement of the soda fluorescence on paper. The technique used was that described by Ayres, Simpson and Tait (5) who found that, in measuring $0.5 \mu \mathrm{g}$ of aldosterone diacetate, the standard error was 0.01 and the standard errors for measurement of 2,4 , and $8 \mu \mathrm{g}$ were, respectively, $0.17,0.43$, and 0.73 . In experiments in this laboratory, the standard error for measurement of $1 \mu \mathrm{g}$ of cortisone was found to be 0.04 .

* Presented in part at the May, 1959 Meetings of the American Society for Clinical Investigation. (J. clin. Invest. 1959, 38, 986.)

$\dagger$ Present address: St. Thomas' Hospital, London, England.
Mean and pulse pressures in brachial and lingual arteries and right atrium, and pressures in femoral vein and esophagus, were measured by means of indwelling cannulae and Statham pressure transducers, and recorded continuously on a Sanborn 8-channel recorder. Serial hematocrit determinations were made. In all experiments blood loss was continuously measured, and replaced by transfusion. Blood used for transfusion was obtained from dogs rendered hypervolemic by large saline infusions immediately before bleeding in order to prevent rise in aldosterone-stimulating substances.

Twenty-seven studies were performed on 25 normal dogs, 4 on 3 dogs with carotid arteries stripped of their nerve supply from low in the neck to above the carotid sinuses, 8 on dogs with carotid sinuses denervated but the neck otherwise undisturbed, and 31 on 18 dogs after denervation of the thyrocarotid arterial junctions, with intact carotid sinuses. These operations were performed 3 days to 5 weeks prior to the acute experiments.

Aldosterone secretion was stimulated by supradiaphragmatic inferior vena cava constriction (6) in 29 experiments. In 22 studies the stimulus was bilateral constriction of the common carotid arteries low in the neck, effected by means of chokers consisting of silk loops passed about the arteries and through double tubes sus-

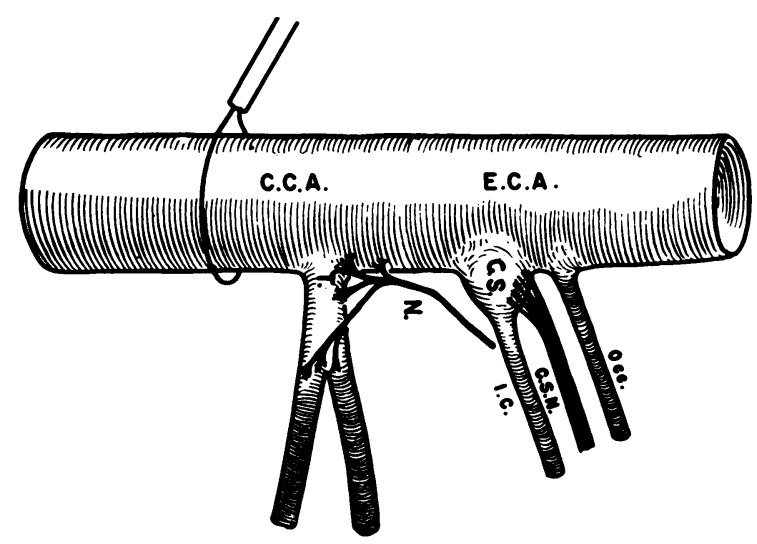

Fig. 1. The anatomy of the Carotid REgion in the DoG. Occ. = occipital artery; C.S.N. = carotid sinus nerve; I.C. = internal carotid artery; C.S. = carotid sinus; E.C.A. = external carotid artery ; C.C.A. = common carotid artery; N. = nerve arising from thyrocarotid arterial junction; $\mathrm{T} .=$ thyrocarotid arterial junction. 
NORMAL DOG CAROTID CONSTRICTION

10-9-58
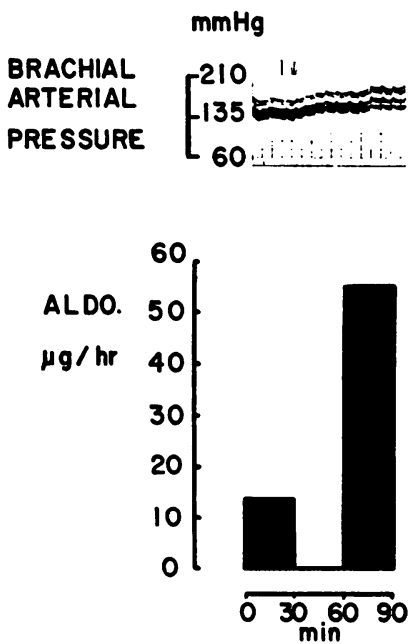

Fig. 2. The Response of BRachial arterial presSURE AND ALDOSTERONE SECRETION TO BILATERAL COMMON CAROTID CONSTRICTION IN A NORMAL DOG.

pended above the arteries. The position of a choker and relevant anatomy are shown diagrammatically in Figure 1 .

In each experiment adrenal venous blood was collected to obtain a control value for aldosterone before application of the constriction. All collections were of 30 minute duration. The next collection was begun 30 minutes after constriction. In most experiments, the constriction was then removed, and a sample of blood collected after 1 hour. Following this collection, the constriction was reapplied, and a further sample collected after 30 minutes. In the 90 minutes allowed following release of carotid constriction, aldosterone secretion seldom returned to control levels in normal or in sinus-denervated animals. Data from the second constriction are accordingly excluded from this series (Tables I and III). All specimens from a given experiment were carried through the chromatographic systems together. Each aldosterone value obtained during constriction was referred to its own previous control value for analysis. Each datum thus consisted of a pair of values obtained during control and subsequent constriction.

\section{RESULTS}

Effect of carotid constriction in normal dogs. Bilateral constriction of the common carotid arteries in normal dogs initiated the classical Hering reflex (7), the fall in intracarotid pressure giving rise to increased peripheral arterial pressure. In addition, aldosterone secretion was consistently elevated within 60 minutes of constriction. One
TABLE I

Effect of bilateral common carotid artery constriction on aldosterone secretion, adrenal plasma flow and brachial arterial pressure in intact dogs*

\begin{tabular}{|c|c|c|c|c|c|}
\hline \multicolumn{3}{|c|}{ Control } & \multicolumn{3}{|c|}{ Carotid constriction } \\
\hline $\begin{array}{c}\text { Aldo- } \\
\text { sterone }\end{array}$ & $\begin{array}{l}\text { Adrenal } \\
\text { plasma } \\
\text { flow }\end{array}$ & $\begin{array}{l}\text { Brachial } \\
\text { arterial } \\
\text { pressure }\end{array}$ & $\begin{array}{l}\text { Aldo- } \\
\text { sterone }\end{array}$ & $\begin{array}{l}\text { Adrenal } \\
\text { plasma } \\
\text { flow }\end{array}$ & $\begin{array}{l}\text { Brachial } \\
\text { arterial } \\
\text { pressure }\end{array}$ \\
\hline$\mu g / h r$ & $m l / h r$ & $m m \mathrm{Hg}$ & $\mu g / h r$ & $m l / h r$ & $m m \mathrm{Hg}$ \\
\hline 3.7 & 196 & $170 / 130$ & 7.8 & 160 & $195 / 155$ \\
\hline 1.9 & 208 & $140 / 120$ & 6.7 & 234 & $144 / 116$ \\
\hline 20.6 & 94 & $176 / 152$ & 29.4 & 90 & $216 / 184$ \\
\hline 8.5 & 58 & $136 / 116$ & 7.2 & 56 & $160 / 132$ \\
\hline 3.9 & 118 & $148 / 120$ & 5.9 & 144 & $166 / 138$ \\
\hline 4.4 & 34 & $174 / 152$ & 7.8 & 24 & $182 / 150$ \\
\hline 5.3 & 102 & $170 / 140$ & 10.0 & 88 & $172 / 140$ \\
\hline 9.0 & 130 & $154 / 122$ & 12.3 & 88 & $162 / 142$ \\
\hline 4.0 & 62 & $166 / 140$ & 9.9 & 40 & $170 / 142$ \\
\hline 3.7 & 76 & $168 / 135$ & 8.6 & 64 & $177 / 144$ \\
\hline 20.0 & 256 & $153 / 123$ & 27.0 & 202 & $162 / 132$ \\
\hline 13.7 & 80 & $153 / 129$ & 55.3 & 42 & $168 / 148$ \\
\hline 3.4 & 72 & $207 / 138$ & 17.0 & 56 & $210 / 150$ \\
\hline 17.0 & 64 & $96 / 84$ & 20.4 & 86 & $108 / 90$ \\
\hline
\end{tabular}

* Each value obtained during constriction is shown with its own control, obtained before constriction was begun.

such experiment is shown in Figure 2, and the data for all experiments of this type are shown in Table I and summarized in Figure 5. Carotid constriction thus produced increased aldosterone secretion associated with increased peripheral arterial pressure.

Effects of carotid constriction in dogs with carotid arteries stripped. Constriction of the carotid arteries in these four animals produced neither reflex hypertension nor increase in aldosterone secretion. One such experiment is shown in Fig-
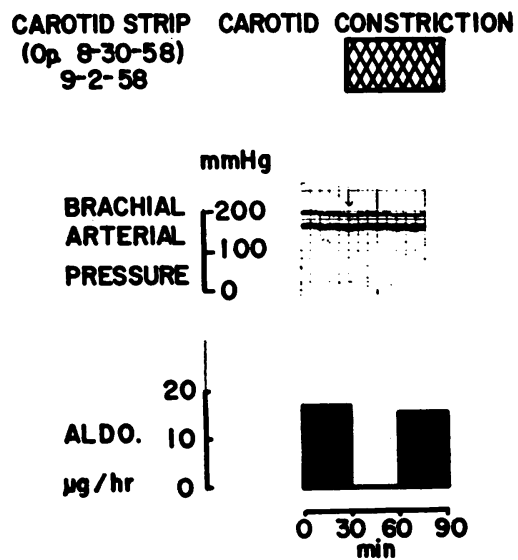

Fig. 3. THE RESPONSE OF BRACHIAL ARTERIAL PRESSURE AND ALDOSTERONE SECRETION TO CAROTID CONSTRICTION IN A DOG WITH BOTH CAROTID ARTERIES STRIPPED OF NERVOUS CONNECTIONS FROM LOW IN THE NECK TO ABOVE THE CAROTID SINUSES. 
TABLE II

Effect of bilateral common carotid artery constriction on aldosterone secretion, adrenal plasma flow and brachial arterial pressure in dogs with both carotid arteries stripped of nervous connections from low in the neck to above the carotid sinuses*

\begin{tabular}{|c|c|c|c|c|c|}
\hline \multicolumn{3}{|c|}{ Control } & \multicolumn{3}{|c|}{ Carotid constriction } \\
\hline $\begin{array}{l}\text { Aldo- } \\
\text { sterone }\end{array}$ & $\begin{array}{c}\text { Adrenal } \\
\text { plasma } \\
\text { flow }\end{array}$ & $\begin{array}{l}\text { Brachial } \\
\text { arterial } \\
\text { pressure }\end{array}$ & $\begin{array}{l}\text { Aldo- } \\
\text { sterone }\end{array}$ & $\begin{array}{l}\text { Adrenal } \\
\text { plasma } \\
\text { flow }\end{array}$ & $\begin{array}{l}\text { Brachial } \\
\text { arterial } \\
\text { pressure }\end{array}$ \\
\hline$\mu g / h r$ & $m l / h r$ & $m m H g$ & $\mu g / h r$ & $m l / h r$ & $m m \mathrm{Hg}$ \\
\hline 16.9 & 174 & 216 & 15.5 & 166 & $172 / 140$ \\
\hline $0(<0.5)$ & 224 & $153 / 114$ & 2.3 & 150 & $156 / 12$ \\
\hline 1.6 & 124 & $156 / 138$ & 1.1 & 68 & $153 / 144$ \\
\hline $1.0 \dagger$ & 42 & $180 / 159$ & 2.0 & 38 & $177 / 153$ \\
\hline
\end{tabular}

* See footnote, Table I.

+ Second constriction.

ure 3, and the data for these experiments are shown in Table II. Stripping the carotid arteries thus abolished both of the responses to carotid constriction seen in the normal animals.

Effects of carotid constriction in dogs with carotid sinuses denervated. Constriction of the carotid artery in these animals produced increase in aldosterone secretion in six out of eight dogs, despite abolition of the Hering reflex by carotid sinus denervation. ${ }^{1}$ Thus, no elevation of periph-

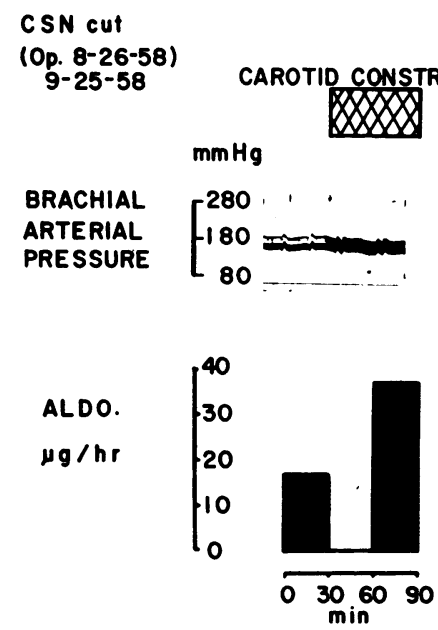

Fig. 4. The RESPONSE OF BRAChial ARTERIAL PRESSURE AND ALDOSTERONE SECRETION TO BILATERAL COMMON CAROTID CONSTRICTION IN A DOG WITH BOTH CAROTID SINUS NERVES CUT. There is a rise in aldosterone in the absence of a reflex rise in brachial arterial pressure (Hering reflex).

1 The remaining two were early experiments, in which the nerves from the thyrocarotid junctions may have been injured inadvertently.
TABLE III

Effect of bilateral common carotid artery constriction on aldosterone secretion, adrenal plasma flow and brachial arterial pressure, in dogs with both carotid sinuses denervated*

\begin{tabular}{rccccccc}
\hline \hline \multicolumn{3}{c}{ Control } & & \multicolumn{3}{c}{ Carotid constriction } \\
\cline { 1 - 3 } \cline { 5 - 6 } $\begin{array}{c}\text { Aldo- } \\
\text { sterone }\end{array}$ & $\begin{array}{c}\text { Adrenal } \\
\text { plasma } \\
\text { flow }\end{array}$ & $\begin{array}{c}\text { Brachial } \\
\text { arterial } \\
\text { pressure }\end{array}$ & & $\begin{array}{c}\text { Aldo- } \\
\text { sterone }\end{array}$ & $\begin{array}{c}\text { Adrenal } \\
\text { plasma } \\
\text { flow }\end{array}$ & $\begin{array}{c}\text { Brachial } \\
\text { arterial } \\
\text { pressure }\end{array}$ \\
\cline { 1 - 3 }$\mu g / h r$ & $m l / h r$ & $m m ~ H g$ & & $\mu g / h r$ & $m l / h r$ & $m m ~ H g$ \\
12.7 & 110 & $210 / 189$ & & 32.8 & 83 & $210 / 189$ \\
7.1 & 80 & $134 / 110$ & & 15.1 & 70 & $136 / 112$ \\
10.1 & 156 & $200 / 160$ & & 4.4 & 200 & $206 / 164$ \\
17.0 & 300 & $150 / 126$ & & 37.0 & 208 & $141 / 114$ \\
7.0 & 114 & $196 / 130$ & & 4.7 & 112 & $180 / 140$ \\
15.9 & 80 & $201 / 171$ & & 25.8 & 80 & $192 / 159$ \\
24.2 & 194 & $200 / 172$ & & 55.6 & 258 & $192 / 152$ \\
5.6 & 114 & $150 / 122$ & & 6.4 & 96 & $160 / 134$ \\
& & & & & &
\end{tabular}

* See footnote, Table I.

eral pressure, heart rate (or, by inference, cardiac output), accompanied the increases in aldosterone secretion. One such experiment is illustrated in Figure 4, and the data for this group of experiments are shown in Table III and summarized and compared with those from intact animals in Figure 5. There is no significant difference in al-

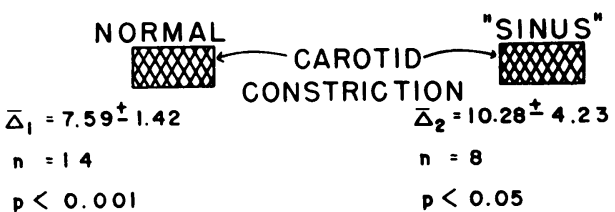

ALDO
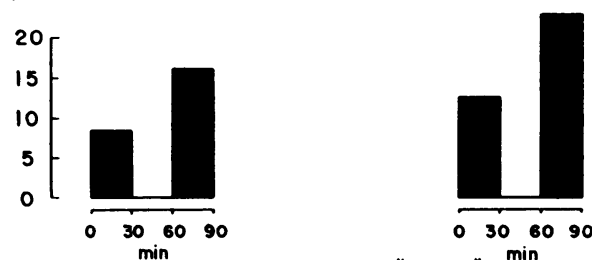

NORMAL Ys. "SINUS" min

$$
\begin{aligned}
& t \equiv \frac{\bar{\Delta}_{1}-\bar{\Delta}_{2}}{\sigma_{1}}=0.6 \\
& n=22 \\
& p>0.5
\end{aligned}
$$

Fig. 5. The RESPONSE OF ALDOSTERONE SECRETION TO BILATERAL COMMON CAROTID CONSTRICTION IN TWO GROUPS OF EXPERIMENTS. On the left, intact animals. On the right, animals previously sinus-denervated. Above each pair of bars (mean values) is a statistical summary of the data. Below the bars, the two groups are compared by means of the $t$ test. $\bar{\triangle}=$ mean change in aldosterone from before to during constriction; $n=$ number of pairs of values (control and during constriction). A highly significant rise in aldosterone secretion is associated with carotid constriction, and there is no significant difference between the normal and sinus-denervated groups. 

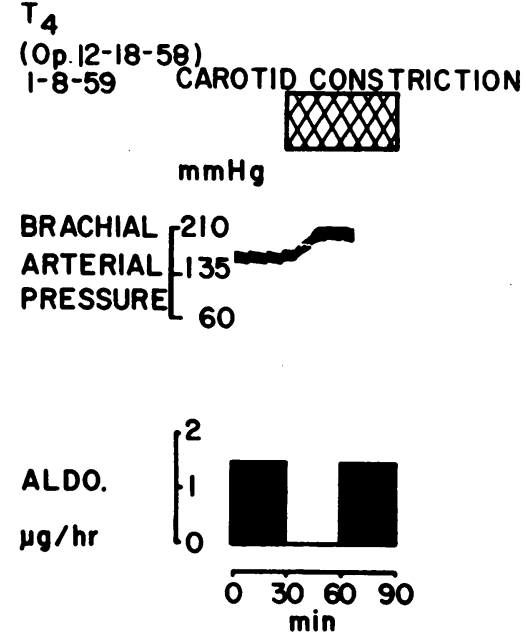

Fig. 6. THE RESPONSE OF BRAChIAL ARTERIAL PRESSURE AND ALDOSTERONE SECRETION TO BILATERAL COMMON CAROTID CONSTRICTION IN A DOG WITH BOTH THYROCAROTID ARTERIAL JUNCTIONS PREviously DENERVATED. There is no rise in aldosterone secretion but an intact Hering reflex.

dosterone secretion in response to carotid constriction between sinus-denervated and intact animals.

Effects of carotid constriction in dogs with thyrocarotid junction denervation. Constriction of the carotid arteries in dogs in which both thyro-

TABLE IV

Effect of bilateral common carotid artery constriction on aldosterone secretion, adrenal plasma flow and brachial arterial pressure, in dogs with denervation of both thyrocarotid arterial junctions*

\begin{tabular}{|c|c|c|c|c|c|}
\hline \multicolumn{3}{|c|}{ Control } & \multicolumn{3}{|c|}{ Carotid constriction } \\
\hline $\begin{array}{l}\text { Aldo- } \\
\text { sterone }\end{array}$ & $\begin{array}{c}\text { Adrenal } \\
\text { plasma } \\
\text { flow }\end{array}$ & $\begin{array}{l}\text { Brachial } \\
\text { arterial } \\
\text { pressure }\end{array}$ & $\begin{array}{l}\text { Aldo- } \\
\text { sterone }\end{array}$ & $\begin{array}{c}\text { Adrenal } \\
\text { plasma } \\
\text { flow }\end{array}$ & $\begin{array}{l}\text { Brachial } \\
\text { arterial } \\
\text { pressure }\end{array}$ \\
\hline$\mu g / h r$ & $m l / h r$ & $m m H g$ & $\mu g / h r$ & $m l / h r$ & $m m \mathrm{Hg}$ \\
\hline 8.5 & 40 & $141 / 114$ & 3.8 & 40 & $168 / 141$ \\
\hline 1.1 & 26 & $96 / 81$ & 1.7 & 22 & $111 / 96$ \\
\hline 8.8 & 130 & $153 / 129$ & 4.4 & 72 & $175 / 141$ \\
\hline $16.0 \dagger$ & 54 & $156 / 138$ & 11.2 & 40 & $216 / 180$ \\
\hline 35.7 & 90 & $141 / 108$ & 8.5 & 66 & $156 / 132$ \\
\hline $1.4 \dagger$ & 48 & $174 / 153$ & 1.4 & 40 & $222 / 198$ \\
\hline 15.9 & 248 & $150 / 96$ & 6.1 & 174 & $156 / 114$ \\
\hline $6.9 \dagger$ & 116 & $156 / 132$ & 5.3 & 114 & $168 / 141$ \\
\hline $11.3^{\circ}$ & 98 & $164 / 144$ & 11.0 & 80 & $186 / 164$ \\
\hline 8.1 & 108 & $140 / 104$ & 5.7 & 110 & $176 / 144$ \\
\hline 6.1 & 54 & $140 / 116$ & 6.6 & 88 & $148 / 108$ \\
\hline 33.5 & 76 & $159 / 129$ & 19.0 & 58 & $186 / 156$ \\
\hline 12.7 & 78 & $162 / 122$ & 13.2 & 70 & $177 / 144$ \\
\hline $3.1 \dagger$ & 42 & $156 / 124$ & 1.8 & 112 & $180 / 144$ \\
\hline $38.0 \dagger$ & 66 & $174 / 141$ & 30.0 & 44 & $195 / 168$ \\
\hline
\end{tabular}

* See footnote, Table I.

† Second constriction.
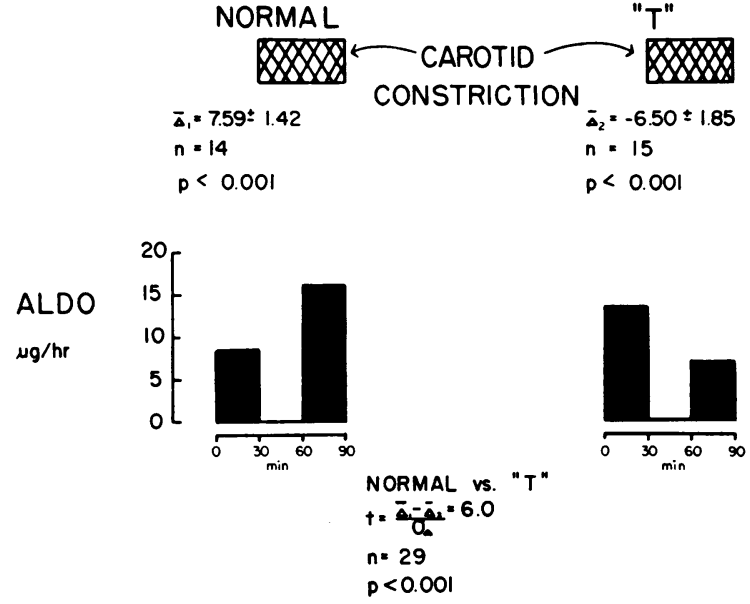

Fig. 7. The RESPONSE OF ALDOSTERONE SECRETION TO CAROTID CONSTRICTION IN TWO GROUPS OF EXPERIMENTS. On the left, intact animals. On the right, animals with previous denervation of both thyrocarotid arterial junctions. The data are arranged as in Figure 5. The fall in aldosterone is highly significant in the group on the right, and the difference between the two groups is highly significant.

carotid arterial junctions had been previously denervated produced no increase in aldosterone secretion despite the presence of intact Hering reflexes. Indeed, in most of these experiments, aldosterone secretion actually fell. One such experiment is shown in Figure 6, and the data for this group of experiments are shown in Table IV

TABLE V

Effect of supradiaphragmatic inferior vena cava constriction on aldosterone secretion*

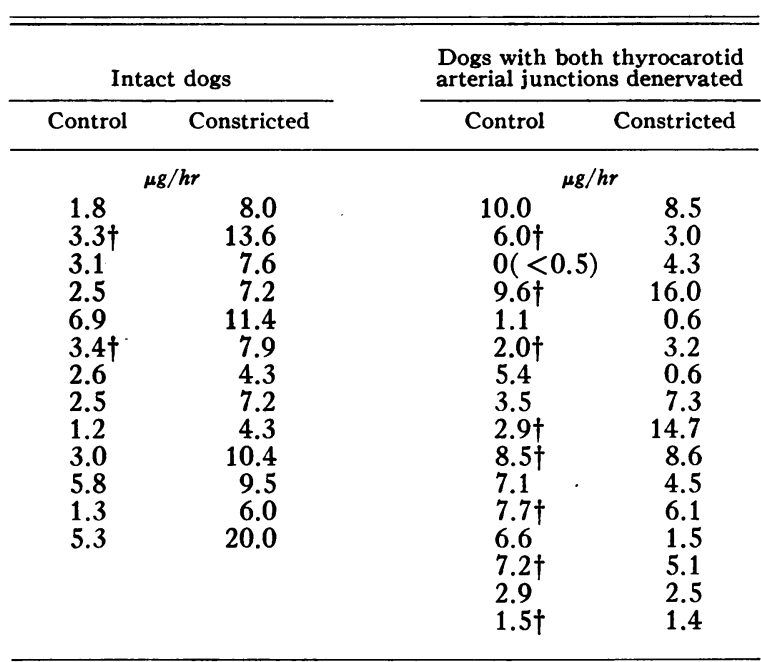

* See footnote, Table I.

$\dagger$ Second constriction. 


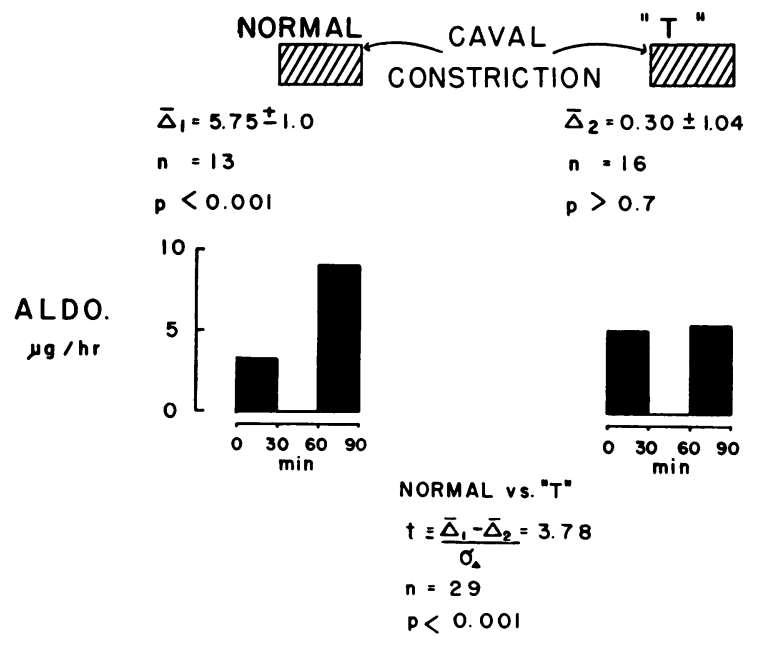

Fig. 8. The RESPONSE OF ALDOSTERONE SECRETION TO CONSTRICTION OF THE INFERIOR VENA CAVA IN TWO GROUPS of EXPERIMENTS. On the left, intact animals. On the right, animals with previous denervation of both thyrocarotid arterial junctions. The data are arranged as in Figure 5. The difference between the two groups is highly significant.

and summarized and compared with those from intact animals in Figure 7. Thus, thyrocarotid arterial junction denervation prevented the rise in aldosterone secretion following carotid constriction without abolishing the rise in peripheral arterial pressure.

Effects of caval constriction in normal dogs and in dogs with thyrocarotid arterial junction denervation. Constriction of the supradiaphragmatic inferior vena cava is a well documented stimulus to increase of aldosterone secretion $(1,6)$. The results of this procedure in 11 normal dogs are shown in Table V. In dogs in which the thyrocarotid arterial junctions had been previously denervated, an exactly comparable degree of caval constriction had no consistent effect on the secretion of aldosterone. The results of this procedure in 16 experiments are shown in Table V. The data are summarized and compared in Figure 8 .

\section{DISCUSSION}

These data suggest a dual mechanism regulating the secretion of aldosterone, whereby stimuli mediating increases are conveyed to the central nervous system via the nerves originating at the thyrocarotid arterial junctions, while those mediating recreases are conveyed via the vagus nerves. It has been shown previously (1) that vagotomy alone does not produce an increase in the rate of aldosterone secretion. Carotid constriction, on the other hand, is evidently an adequate stimulus to increase of aldosterone secretion. This increase is independent of pressure changes in the peripheral arterial (extracarotid) system. This is clearly demonstrated by the continued effectiveness of the stimulus after carotid sinus denervation as well as by the ineffectiveness of the stimulus, despite intact pressure response, in animals with thyrocarotid arterial junction denervation. ${ }^{2}$

It has previously been suggested that aldosterone secretion is regulated by some function of extracellular (8) or intravascular (2) fluid volume. The present data suggest that the significant parameter is some function of intracarotid blood volume. The data presented here do not indicate what that effective parameter is, but evidence drawn fram these and other experiments (9) suggests that it is primarily a decrease in intracarotid pulse pressure which leads to the increase in aldosterone secretion.

Farrell (10) has suggested that aldosterone secretion is regulated principally by means of intracranial receptors, primarily measuring sodium concentration. Evidence from experiments in man, on the other hand, suggests that neither serum sodium concentration nor total body sodium can control aldosterone secretion, which can be made to vary independently of both (8). The present data, in addition, provide a mechanism whereby the central nervous system may receive afferent impulses from the periphery leading to increase or decrease in aldosterone secretion. Thus, it is no longer necessary to postulate the existence of central receptors. However, the existence of such receptors is not excluded by these experiments which, in particular, shed no light on the mechanism by which changes in body potassium may modify aldosterone secretion.

If, as is suggested by these experiments, there is central integration of afferent impulses modifying aldosterone secretion, then it is possible that the central nervous system releases a hormone

2 Table $\mathrm{V}$ includes four pairs of values (from two dogs) in which aldosterone secretion rose with constriction. It seems likely, in retrospect, that denervation was not complete in these animals. The data were not excluded from analysis. 
which regulates adrenal secretion of aldosterone and constitutes the efferent limb of this reflex, as was previously suggested by Rauschkolb and Farrell (11). Evidence for the existence of such a hormone has been supplied by both Denton, Goding and Wright (12) and Yankopoulos, Davis, Kliman and Peterson (13). [In the former experiments, however, aldosterone was not measured directly, but was estimated from changes in salivary $\mathrm{Na}: \mathrm{K}$ ratios. On the other hand, there is evidence $(14,15)$ that adrenal isolation is not complete in the preparation of Hilton and co-workers (16) used in the latter experiments. Accordingly, blood pressure or pharmacological changes in the recipient animal could themselves be adequate stimuli to increase in aldosterone secretion. Hemodynamic changes and norepinephrine (17) have both been shown to alter baroceptor activity, which, in turn, may modify aldosterone secretion (9). Furthermore, cross circulation itself results in maximal secretion of Porter-Silber steroids (18). Under this circumstance, further increase of ACTH secretion may cause a rise in aldosterone secretion without changing corticosterone secretion (19). Thus, increase in the aldosterone: corticosterone ratio is not in itself sufficient evidence of a stimulating substance other than ACTH.] Although it seems likely that a neurohormone is active in the control of aldosterone secretion, its existence has not as yet been adequately demonstrated.

In these experiments, it has clearly been possible to measure rises in aldosterone secretion. In the preparation used by Farrell and associates, this was not possible, as all experimental animals secreted at maximal rates $(10,20)$, presumably as a result of the blood loss which is an integral part of that method. Accordingly, control data were derived from other animals. In the present experiments, blood was replaced as it was lost, and each animal could serve as its own control.

The apparent difference between the effects of carotid and caval constrictions in dogs with previous thyrocarotid arterial junction denervation, in which the first group showed lowering of aldosterone secretion ( $\mathrm{p}<0.001$ ), while the second showed no change in aldosterone secretion, is not well explained. However, carotid constriction causes a reflex increase in right atrial pulse pressure (21), while atrial pressure is lowered with caval constriction. It is possible that this increase in pressure activates the "decrease" mechanism mediated by the vagus nerves, thus accounting for the lowering of aldosterone with carotid constriction in the presence of thyrocarotid denervation.

\section{SUMMARY}

Constriction of the common carotid arteries low in the neck produces increased secretion of aldosterone. This effect is independent of changes in peripheral arterial pressure, but is abolished by bilateral denervation of the thyrocarotid arterial junctions. The rise in aldosterone normally seen with constriction of the inferior vena cava is also prevented by denervation of this region. It is suggested that aldosterone secretion is regulated by a dual mechanism, in which decreases in secretion are mediated by the vagus nerves, while increases in secretion are mediated primarily by receptors located at the thyrocarotid arterial junction. Aldosterone secretion may thus be increased by local decrease in intracarotid volume, independent of total extracellular or even intravascular volumes.

\section{REFERENCES}

1. Mills, I. H., Casper, A. G. T., and Bartter, F. C. On the role of the vagus in the control of aldosterone secretion. Science 1958, 128, 1140.

2. Bartter, F. C. The role of aldosterone in the regulation of body fluid volume and composition. Scand. J. clin. Lab. Invest. 1957, 10, suppl. 31, 50.

3. Hume, D. M., and Nelson, D. H. Adrenal cortical function in surgical shock. Surg. Forum 1955, 5, 568.

4. Neher, R., and Wettstein, A. Physicochemical estimation of aldosterone in urine. J. clin. Invest. 1956, 35, 800.

5. Ayres, P. H., Simpson, S. A., and Tait, J. F. A fluorescence method for the microanalysis of $\Delta 4-3$ oxo steroids on paper chromatograms. Biochem. J. 1957, 65, 647.

6. Davis, J. O., Pechet, M. M., Ball, W. C., Jr., and Goodkind, M. J. Increased aldosterone secretion in dogs with right-sided congestive heart failure and in dogs with thoracic inferior vena cava constriction. J. clin. Invest. 1957, 36, 689.

7. Hering, H. E. Die Karotissinusreflexe auf Herz und Gefässe vom normal-physiologischen, pathologischphysiologischen und klinischen Standpunkt (gleichzeitig über die Bedeutung der Blutdruckzügler für den normalen und abnormalen Kreislauf). Leipzig, Steinkopff, 1927.

8. Bartter, F. C., Liddle, G. W., Duncan, L. E., Jr., Barber, J. K., and Delea, C. The regulation of 
aldosterone secretion in man: The role of fluid volume. J. clin. Invest. 1956, 35, 1306.

9. Gann, D. S., Mills, I. H., and Bartter, F. C. On the hemodynamic parameter mediating increase in aldosterone secretion in the dog. Fed. Proc. In press.

10. Farrell, G. Regulation of aldosterone secretion. Physiol. Rev. 1958, 38, 709.

11. Rauschkolb, E. W., and Farrell, G. L. Evidence for the diencephalic regulation of aldosterone secretion. Endocrinology 1956, 59, 526.

12. Denton, D. A., Goding, J. R., and Wright, R. D. Control of adrenal secretion of electrolyte-active steroids. Brit. med. J. 1959, 2, 447.

13. Yankopoulos, N. A., Davis, J. O., Kliman, B., and Peterson, R. E. Evidence that a humoral agent stimulates the adrenal cortex to secrete aldosterone in experimental secondary hyperaldosteronism. J. clin. Invest. 1959, 38, 1278.

14. Casper, A. G. T., Mills, I. H., and Bartter, F. C. Unpublished observations.
15. Hilton, J. G., Scian, L. F., Westermann, C. D., and Kruesi, O. R. Effect of synthetic lysine vasopressin on adrenocortical secretion. Science 1959, 129, 971.

16. Hilton, J. G., Weaver, D. C., Muelheims, G., Glaviano, V. V., and Wegria, R. Perfusion of the isolated adrenals in situ. Amer. J. Physiol. 1958, $192,525$.

17. Landgren, S., Neil, E., and Zotterman, Y. The response of the carotid baroceptors to the local administration of drugs. Acta physiol. scand. 1952, $25,24$.

18. Hume, D. M., and Egdahl, R. H. Personal communication.

19. Mulrow, P. J. Personal communication.

20. Sayers, G., Redgate, E. S., and Royce, P. C. Hypothalamus, adenohypophysis and adrenal cortex. Ann. Rev. Physiol. 1958, 20, 243.

21. Gann, D. S., and Bartter, F. C. Buffer function of the nerves arising at the thyrocarotid arterial junction in the dog. Amer. J. Physiol. 1959, 197, 1229. 